\title{
MAPPING TERRITORIES, LAND RESOURCES AND RIGHTS: COMMUNITIES DEPLOYING PARTICIPATORY MAPPING/PGIS IN LATIN AMERICA
}

Michael K. McCall ${ }^{1}$

\section{INTRODUCTION}

The paper addresses the relations between land and peoples - a core element in human geography and political ecology - from the perspective of how people represent and map their land. Maps are powerful tools reflecting the influence and priorities of the actors who create them, and in turn the maps can act as instruments to shape new spatial realities. Therefore there is an imperative need for more participation in the making of maps by the people who are affected by them. Participation in mapping encompasses the preparation and design as well as the implementation of a mapping process, and the control and applications of the map outputs. In this paper, conventional mapping activities as well as GIS, when performed participatorily or collaboratively, are included under the methodological approach termed PGIS (Participatory GIS).

The focus is on people - in particular local and indigenous peoples - and their environments in Latin America, on their local spatial knowledge (LSK), and on the representations (mainly in maps) which they make of the lands and resources surrounding them.

The paper addresses four questions:

$\checkmark$ 'What is the value-added of participation in mapping and GIS?' (section 1)

$\checkmark$ 'What is the transformative significance of mapping land and resources for communities and peoples in Latin America?' (section 2)

$\checkmark$ 'What are the salient objects and subjects of this mapping?' (section 3)

$\checkmark \quad$ 'How can participatory mapping and participatory GIS (PGIS) be effectively carried out - in good practice?' (section 4)

Section 5 addresses challenges with PGIS in this context, and section 6, conclusions.

\footnotetext{
${ }^{1}$ CIGA, Universidad Nacional Autónoma de México, ITC, University of Twente, Netherlands.
} 


\section{Origins and Value-added of Participation in Mapping and GIS}

Ideologically, a primary fount of the participatory approach in working with local people's knowledge (including their LSK) lies in the alternative education, activism, and political commitment to progressive values of empowerment and equity and 'liberation theology', which emerged in Latin America in the 1970s. This radical stream took off from the critical pedagogy of Paulo Freire (1970) as a response to 'normal' formal modes of education where the "teacher" stands at the front and "imparts" information to "students" who are passive recipients. Freire wrote, "The silenced are not just incidental to the curiosity of the researcher but are the masters of inquiry into the underlying causes of the events in their world. In this context research becomes a means of moving them beyond silence into a quest to proclaim the world." (Freire 1982, 30-31)

From its origins in Brazil, Freire and others developed this further in "adult education" models throughout Latin America, and, based on Freire's ideas, Orlando Fals-Borda developed PAR (participatory action research) with a seminal conference in Cartagena. Based on his rural programme experiences Fals-Borda was able to effectively incorporate a "community action research" component into research (Fals-Borda \& Mora-Osejo 2003).

Both practitioners and analysts recognise that all processes in which people participate effectively in the processes of knowledge acquisition, analysis, evaluation, decision-making and planning have the potential to be 'empowering'. Thus the very actions of P-mapping and PGIS help to empower people, through their practical involvement in mapping, measuring and monitoring. An effective and engaged involvement gives local people a greater capacity and confidence to influence the processes of problem prioritising, information selection, intervention identification, which otherwise tare the preserve of external agents and 'experts'. A sustained involvement further creates learning, skill development, and some sense of 'ownership'.

Latin American examples show the principle that the participatory mapping processes themselves are transformatory and creative. Cochran (2008) assessed the value of "PRM" (participatory research mapping) in terms of empowering marginalised communities in eastern Honduras. In Nicaragua, Miskitu Indians actively produced and transformed knowledge - 'the 
very process of data collection transforms the object of inquiry' (Gordon et al. 2003), who further argue that it 'becomes pointless to distinguish between original, essentialist attitudes, entitlements, and conceptualisations of land, and the constructed identities' which emerge from the participatory mapping activities - 'they elide into each other'. Other PAR researchers have made similar discoveries and conclusions, for examples, Herlihy and Knapp (2003), and Chapin and Threlkeld (2001 Indigenous Landscapes: A Study in Ethnocartography).

In the urban community context, it is similarly argued that community mapping provides an inclusive and graphical framework for people to affirm and pool their experiences and knowledge about their home place. Global good practice in urban community mapping includes Green Maps (www.greenmap.org, www.greenmap.com/home/home.html), a participatory, creative educational mapping tool based on active engagement, mainly in urban areas. The Green Map system has a locally adaptable framework for environmental mapmaking, using a shared visual language, a set of Icons representing different kinds of green sites and cultural resources. About 65 countries (850 examples, 2014) - in Latin America these include Argentina, Brazil, Chile, Colombia, Costa Rica, Cuba, Jamaica, Peru, and Uruguay.

There are few other specifically urban examples from Latin America, but notable are ACT Brazil (2008), and Wagner Berno de Almeida et al. (2009), as part of Nova Cartografia Social da Amazônia (n.d.) which includes mapping by indigenous peoples living in Amazonian cities; see also Fuentes and Reyes (2008) in Colombia.

In sum, the value-added of participatory mapping and PGIS follows from its key principles of: (a) empowering through participation - Korten (1986) called this the "generative or creative power" of participation, as additional to the "distributive power" of participation towards equity by redistributing benefits and resources; (b) aiming for characteristics of flexibility, adaptiveness, and on-goingness; (c) respect for local knowledge, which is related to (d) awareness and utilisation of local and locational specificity; and, (e) being reflexive, and self-aware in its recognition of agency and power.

An analysis of the objectives and intentions which explain why external agencies jump to promote participatory approaches - that is, to facilitate projects, to mediate, or, to promote 'empowerment', have been analysed by McCall (2003) and McCall and Dunn (2012). 


\section{Contextual Land Issues in Latin America - Loss of Territory, Loss of Resources, Loss of}

\section{Identity}

Latin American economies and society face a degradation of the environmental and natural resource spaces, brought about by a combination of the pressures from growing population, continuing poverty inequities, and an accumulation of globalisation impacts. These lands - and the people who populate them are facing increasing external pressures on their territories, from expanding farmlands and pasturelands of other social groups, accelerating exploitation of minerals, petroleum, gold, etc., mainly for external markets, deforestation and degradation, and unsustainable forest resource exploitation, as well as road building, land flooded for hydroelectric dams, etc.

Central to this argument is that local indigenous peoples are frequently (depending on their geographical situation) responsible for the good management of resources and landscapes. This is clearly seen in upper watersheds, which provide many environmental benefits for other actors 'downstream' and elsewhere, thus the increasing interest in community participation in PES (payment for environmental services) programmes, to create compensation for sound management of the community space.

The arguments above already call for investigating how local people can be supported in local landscape management. But there are additional strong principles, including political and good governance arguments towards devolution and participation. The moral and ethical position is grounded in the rights of indigenous/local people to remain in their territorial lands, to utilise them for their own sustainable quality of life, and to receive the benefits of these lands and resources (ILO 1989, UNDRIP 2007). Losing their land is usually tantamount to losing their identities along with their means of sustainability and livelihoods. Their massive accumulated local knowledge of their landscape is lost, along with their health and their cultures, and eventually, even their languages end up in the linguistic cemetery.

The arguments in this paper are that: 
$\checkmark$ Local inhabitants, indigenous and others, have a moral right to survival, and they have rights to their territory - in the indigenous cases, usually also supported by international articles and national legislation.

$\checkmark$ They have a deep cultural connection with their landscape, - land is not just a market commodity for sale.

$\checkmark$ They are overall more effective managers for the long-term strong sustainability of the landscape.

$\checkmark$ They are heavily dependent on the land and its resources for survival and livelihoods.

$\checkmark$ The local spatial knowledge of the geography of the local space and the people's spatial perceptions are central.

$\checkmark$ Representations of their space (such as maps) need to reflect these moral, cultural, and socio-economic realities.

$\checkmark$ There is a need to counter conventional (external) map-making with the spatial representations of their needs and priorities.

\section{'Mapping What'?}

Of many justifications for community mapping of local space, four significant in practice and potential are considered below.

\section{Claiming 'Our Territory'}

Land is fought for and stolen - encroached, invaded, grabbed, compulsorily acquired. There is no doubting the significance of maps and map-making in these struggles and conflicts and the power games and propaganda that accompany them. 'What are maps really for?' was the question asked by Denis Wood in his polemical book, The Power of Maps. What could be the interests, cultural values and social needs of the map-makers? And his answer was 'military, mining and natural resources, limits of suzerainty - certainly not just for navigation'. (Wood 1992, 2010). 
The primary application of PGIS practices by most indigenous communities has been for claiming, or reclaiming, territorial land rights, usually lost to other groups under colonial or postcolonial regimes. In Latin America as elsewhere, the indigenous nations did not have their traditional areas of use and occupancy and management recognised as legal territorial rights by the invasive authorities. As a means towards (re)claiming their territorial lands, indigenous and local communities throughout North and Latin America are adopting and developing PGIS as an instrument in the defence of their customary lands, and in their court claims for legal and legislative recognition of their territories. Further to this, they are employing PGIS for monitoring infringements by, e.g. pastoralists, agriculturists, commercial foresters or charcoal makers, tourism developments, miners (industrial or artisanal), oil drilling, biofuel plantations (oil palms), prawn farms in mangroves, or, generic land grabbers,

To varying degrees, in different countries, and with different methods these 'first nations' are pursuing their rights in political and legislative and legal arenas. And they are having differing degrees of success. There is a continuum of both the efforts expended and the success achieved from highly-conscious, motivated countries like Bolivia, Nicaragua and Ecuador, through a middle range of Brasil, Peru, Colombia, etc. to the weaker end, e.g. Argentina, Chile, Mexico and some of Central America.

The broad extent of these initiatives are suggested by the range of cases: Peru (Orlove 1993, Smith et al. 2003, Shinai 2004, RROMUEPATSRO 2010); Bolivia (Orlove 1993, Orta Martínez 2010); Brazil (Foster Brown et al. 2005, Heckenberger 2009 who includes archaeological enquiries; ACT Brazil 2008); Colombia (López Urrego 2010, Sletto et al. 2013 - and Latin America in general) Afro descendants in Colombia, (Offen 2011, Sletto et al. 2013, Vélez Torres et al. 2012); Nicaragua (Stocks et al. 2000, Gordon et al. 2003, Offen 2003, Stocks 2003, Dana 2008, Finley-Brooke \& Offen 2009); Honduras (Willmer \& Ketzis 1996); Panama (Herlihy 2003, Herlihy \& Knapp 2003); surprisingly few in Venezuela (Poole 2005, 2006) and Mexico (Kelly et al. 2010, Smith et al. 2012); and even Argentina and Chile (Arias 2012).

Some of the classic works are: Nietschmann (1995), Poole (1995), Toledo Maya Council (1997), Chapin \& Threlkeld (2001), Herlihy and Knapp (2003), and Chapin et al. (2005), 
Spatial representation of customary land systems with communal property regimes is not wellserved by conventional mapping and GIS. Such systems demand a very different approach for dealing with spatial entitlements, boundaries, responsibilities, and perceptions, from the position of the local inhabitants and their local spatial knowledge. The incorporation of PGIS functions into legislated 'modern land law' was initially applied to First Nation territorial claims in Canada (Flavelle 2002; Tobias 2010). It takes in several components making use of community mapping and PGIS procedures: demarcation of the customary 'traditional' boundaries for land and natural resource claims; identification of areas of traditional use and occupancy; negotiating and prioritising claims between different communities; and then, preparation for government legal procedures, now having the benefit of the rigour, accuracy, and visualisation of spatial information now in a geo-referenced GIS / map format.

Table 1 compares customary communal land systems with those of a market economy's cadastral system. The third column demonstrates how a PGIS approach can handle many special characteristics of a customary communal system. Whereas conventional GIS handles cadastral systems very well with precise, fixed, permanent records, it cannot easily handle the rich meanings of customary land; PGIS can cope better.

TABLE 1. PGIS can Represent Customary Communal Land Systems.

\begin{tabular}{|c|c|c|}
\hline Market-oriented Land Tenure & Customary Land Tenure System & $\begin{array}{l}\text { Key Contributions of PGIS for } \\
\text { representing customary systems }\end{array}$ \\
\hline $\begin{array}{l}\text { Land is treated as a marketable } \\
\text { commodity. }\end{array}$ & \begin{tabular}{|c|}
$\begin{array}{c}\text { Spiritual and physical connection } \\
\text { of people to their land. }\end{array}$ \\
\end{tabular} & Multiple linkages of people to land. \\
\hline $\begin{array}{l}\text { Exclusive ownership. Land is } \\
\text { registered in cadastres. }\end{array}$ & $\begin{array}{l}\text { Communal ownership of land. } \\
\text { Attitudes of 'stewardship' of land. }\end{array}$ & Group validation of ownership. \\
\hline $\begin{array}{c}\text { Transfer of land by sale, lease, or } \\
\text { inheritance. }\end{array}$ & $\begin{array}{l}\text { Land is transferred through } \\
\text { cultural membership. }\end{array}$ & Linking spatial to social networks. \\
\hline $\begin{array}{l}\text { Written records are Certificate of } \\
\text { Title granted by the state. Long- } \\
\text { term storage in databases. }\end{array}$ & $\begin{array}{l}\text { Evidence of tenure is via song, } \\
\text { dance, stories, ceremonies. }\end{array}$ & $\begin{array}{c}\text { Use of multi-media. } \\
\text { Incorporative as well as Inscriptive } \\
\text { knowledge. }\end{array}$ \\
\hline $\begin{array}{l}\text { Boundaries are geodetically set, } \\
\text { demarcated by monuments, with } \\
\text { state regulation. }\end{array}$ & $\begin{array}{c}\text { Boundaries are 'limits of } \\
\text { influence' set by topography; } \\
\text { some areas are sacred spaces. }\end{array}$ & $\begin{array}{c}\text { Flexible, fuzzy, temporal boundary } \\
\text { delineation. }\end{array}$ \\
\hline $\begin{array}{l}\text { Place names (toponyms) provided } \\
\text { from official government } \\
\text { gazetteers. }\end{array}$ & $\begin{array}{c}\text { Toponyms are customary, often } \\
\text { differing between local } \\
\text { (indigenous) groups. }\end{array}$ & $\begin{array}{l}\text { Multiple toponyms, with their local } \\
\text { provenances and meanings. }\end{array}$ \\
\hline $\begin{array}{l}\text { Rights on neighbouring lands are } \\
\text { restricted and controlled by the }\end{array}$ & $\begin{array}{l}\text { Overlapping rights and } \\
\text { responsibilities between groups. }\end{array}$ & $\begin{array}{l}\text { Fuzzy, temporal rights spaces. } \\
\text { Layers of rights. Counter maps. }\end{array}$ \\
\hline
\end{tabular}




\begin{tabular}{|c||c|c|}
\hline state. & Negotiate with neighbours. & \\
\hline $\begin{array}{c}\text { 'Hard' boundaries. } \\
\text { Mostly fixed permanent } \\
\text { boundaries. }\end{array}$ & $\begin{array}{c}\text { 'Soft' boundaries. } \\
\text { Temporary, fluid and seasonally- } \\
\text { flexible boundaries. }\end{array}$ & $\begin{array}{c}\text { Flexible, fuzzy, fluid, permeable } \\
\text { boundaries. }\end{array}$ \\
\hline $\begin{array}{c}\text { Land is assigned reductionist, } \\
\text { isolated, precise meanings. }\end{array}$ & $\begin{array}{c}\text { Rich meanings of 'land' give a } \\
\text { holistic view of land. }\end{array}$ & $\begin{array}{c}\text { Multi-media - sound, images, } \\
\text { pictures, etc. } \\
\text { Scale-jumping. }\end{array}$ \\
\hline
\end{tabular}

Table 1 developed after Brazenor's (2000) analysis of Aboriginal customary land and cadastral systems in Australia, and McCall \& Dunn (2012).

A key concept in the claim process is the recognition and provenance of the toponomy. The naming of places, their (recognised) inhabitants and their land resources, is an act of cultural authority and display of power. The cultural, social, and ultimately economic value of toponyms represents ownership, power and cultural hegemony. Therefore PGIS programmes can begin their recording of local spatial knowledge with 'nameless maps', i.e. with no names of settlements and communities, nor even the (externally-nominated) names of rivers and mountains and natural features, (Poole 2005 in Venezuela). "Narrating place and identity" implies the participatory mapping of cultural-historical meanings and identity of place as the signifiers of toponyms in cultural landscapes. See e.g. Offen (2003); O'Connor \& Kroefges (2008); Sletto (2009), Sletto et al. (2010); Carleton University (n.d.).

\section{Infringements and security}

An associated driver is the protection of local community territories against invasion and degradation. These may come from neighbouring local communities (Reyes-García et al. 2012), though most commonly from powerful external agents, government and private sector, e.g. conflicts over Brasil nuts resource area boundaries (Evans et al. 2006; Cronkleton et al. 2010). A threat recently prioritised is pollution. Multinationals and local powerful agents like loggers and ranchers penetrate and desecrate community lands to dump wastes, deforest on a large scale, illegally extract minerals, or simply fail to take due care when handling land and resources. PGIS to defend the physical and social integrity of the community against these invasions contributes at two stages, the initial mapping of the claimed boundaries and resource 
spaces of the local territory (as in 3.1 above), and then the use of PGIS tools and software to monitor, record and report the infringements. Usually the monitoring is a technology-straddling combination of local people's observations based on their traditional LSK of places and things, and modern technology of digital cameras and GPS (combined in PDAs or smart phones) to record and geo-reference the degradations. An example is the participatory development of local PGIS ("MELPGIS") for the Achuar people of Peruvian Amazonia to identify, monitor and publicise the pollution caused by commercial oil exploration and extraction (Orta Martínez 2010)

\section{'Knowing and using resources means mapping the resources'}

Common initial applications of PGIS to natural resources management are to identify, locate, and analyse specific natural resources and their exploitation: forest and woodland resources; trees, non-timber forest products; environmental services; water resources and management; pastoralism and livestock management; soils, especially ethnopedology; land suitability and land evaluation; wildlife management and hunting; fisheries, marine and Inland; or, minerals extraction.

More complex applications are to the holistic management of traditionally-held natural resources systems in local/indigenous lands. : (ii) the maintenance and reproduction of a particular resource or unit; and (ii) the management of broader complex ecosystems containing and nurturing resources, such as wetland farming systems, seasonal nomadic pastoral systems, paramo systems, or Traditional Use Studies in Canadian First Nations.

A broad range of community-based PGIS mapping applications can be found In Latin America for specific resources or for resource management systems, such as: water management (Boelens n.d. Bolivia); ethnopedology (Barrera-Bassols et al. 2009); shade coffee management (MartínezVerduzco et al. 2011 Mexico); home gardens (Mendez et al. 2001 Nicaragua); forest Brasil nuts (Evans et al 2006, Cronkleton et al. 2010); fishing (Nietschmann 1995, Nicaragua; De Freitas \& Tagliani 2009 Brazil); hunting and wildlife (Smith et al. 2003 Peru; Read et al. 2010 Guyana; Dunn \& Smith 2011 Honduras); biomass carbon (Peters-Guarin \& McCall 2011); and natural 
resource management in general (Foster-Brown et al. 1995, Flores et al. 2007, Bernard et al. 2011, Nova Cartografia Social da Amazônia n.d.- all in Brazil; Jardinet 2006 Nicaragua; Smith et al. 2009 Venezuela).

In Latin America, an especial opportunity is the introduction of PGIS into formal land management plans, Ordenamiento Territorial (OT) (local Land Use or Land Management Plans) or Ordenamiento ecologia. OTs vary between different national jurisdictions but normally follow a standard of implementation procedures, priority topics, and data collection and analytical methods. (e.g. Anta Fonseca et al. 2006, in Mexico). Their purpose is to improve and systemise local level community land use and natural resource management. OTs have not generally been designed to be participatory - nothing beyond the first steps on a 'participation ladder' (McCall \& Dunn 2012), that is, the elicitation and some degree of utilisation of local information about resources, which may partially take into account locally-stated needs and problems.

PGIS has high potential in the preparation of OTs, or the re-visioning and revision of existing OTs. Firstly, the PGIS approach Incorporates much more and deeper local environmental knowledge; secondly, local needs and priorities generally are given a high visibility; thirdly, these local priorities can be disaggregated to represent the positions and visions of disadvantaged community sub-groups - this alternative spatial visualisation is known as 'counter-mapping'. Fourthly and significantly, the local 'solutions' are recognised and incorporated into the OT.

\section{Compensation for environmental management and environmental services}

Resources locally managed and claimed are also the environmental services rendered by the sound management practices of communities in forests or upper watersheds or wetlands which provide tangible and intangible benefits for downstream or distant people. Thus communities are entering into the potentials of compensation payments for environmental services.

The mapping, measuring, and monitoring of the quality and extent of the sound management practices which sustain the services, is a function of PGIS. PGIS activities for this application combine the mapping and recording of the initial resources which provide the services (such as water infiltration zones, catchment sediment protection, biodiversity, threatened species zones, 
biomass stocks for carbon sequestration, and ecosystems that support pollenisation media), and combine this with tools and techniques for monitoring the flow of the services and changes. Thus the PGIS outputs are essential for referencing, validation and verification of the services to be compensated, at the same time as the PGIS is used for the actual landscape and resources management.

Eventually communities can build up validatable knowledge of 'resource portfolios' for proving ownership, for sound management systems, and for potentially entering into external PES programmes.

\section{'Mapping How'? Good Practice in PGIS}

\section{PGIS to empower}

In terms of good governance, a PGIS approach and its tools should have the capacity to promote empowerment by opening up the horizons of local users in the community; notwithstanding it is well-recognised that this enlargement of perspective is an aspect of 'modernisation' which could have negative consequences for the local community. The approach should be meeting all the key conditions of 'good governance' - accountability, legitimacy, transparency, competence, respect, equity, and ownership (McCall 2003). Furthermore, participatory approaches create and support further autonomous initiatives within the actors and community, and thus have the potential of being sustained, Participatory approaches should satisfy the majority of the actors, especially supporting the more disadvantaged and less articulate actors, whilst not causing unwarranted harm to any actors. The PGIS technology should be giving voice to local people to the extent of putting them and their local (spatial) knowledge on an equal footing with external 'experts' and decisionmakers and their 'official' information. The communication challenge is to bridge the gap between indigenous and scientific spatial knowledge by providing a translation capability between local stakeholders and external decision-makers. To the extent that PGIS has potential to put the endogenous LSK and language on an equal footing, it enhances the acceptability and 
legitimacy of the tool for the local community users (cf. Abbott et al. 1998; McCall \& Dunn 2012).

Therefore, PGIS can empower local people - (a) it builds local capacity and self-confidence in handling "modern" technologies and instruments (b) local people learn how the outside agencies (in planning, policy-making etc.) deal with spatial information, and (c) as a step towards equity - local communities can talk with government agencies or corporations or big NGOs, and exchange knowledge with outsiders on a more equal basis.

\section{Capabilities required from participatory mapping and PGIS}

Good practice in PGIS and P-mapping processes and procedures requires capabilities to maintain the operational functions and procedures appropriate to handling the geospatial knowledge needs of local communities.

Foremost is the capability to elicit, represent and validate local (including indigenous) spatial knowledge, and treat it with scientific as well as cultural respect. This rich local knowledge is rarely available on official maps or GIS. This is arguably the most significant and valuable criterion for a PGIS contribution. PGIS should rrepresent what is important to people about 'place', acknowledge and value the spatial specificity, and inform about local interests and priorities, values and perceptions. This is the primary driver and focus for participatory mapping and PGIS. The significance of mapping local knowledge - especially of territorial rights and resource entitlements is underlined by Nietschmann's (1995) succinct aphorism that 'More territory has been lost to maps than to guns...'.

PGIS integrates knowledge from local and community experts with validated knowledge from conventional scientific sources and scientific experts. This implies the inclusion of local knowledge that does not necessarily conform to state visions of place; local indigenous spatial knowledge such as sacred knowledge and cosmovisions, gendered and culturally-specific knowledge and values, and group or individual perceptions.

Furthermore, PGIS is socially inclusive by representing the interests, values and priorities of groups and communities as well as of individuals, and especially those of disadvantaged groups. 
PGIS builds counter-mapping to identify and record the spatial knowledge, needs and priorities of 'excluded groups' who are less powerful and less articulate, less integrated into the power structures. These may be ethnic / tribal (such as indigenous) or religious minorities, the land title-less or the poor, the elderly, children, and in some cultures, women. These groups and individuals are frequently excluded from land use policy decisions and especially from land ownership. This marginalisation is both reflected in, and reinforced by, the standard maps of land use and resources created by official survey departments and planning agencies. Counter maps provide the alternative visions (e.g. Rocheleau \& Ross 1995; and the many maps made by Nova Cartografia Social da Amazônia n.d.)

PGIS has very strong potential for representing visions, the mental or cognitive maps of people, including but not exclusively, cosmovisions of indigenous peoples. (c.f. Table 1). Translating mental maps into the two dimensions of paper maps or GIS involves firstly the legitimatisation of the reality of people's cognitive maps, that is, the ontological fuzziness and ambiguity of people's perceptions of spatial location, spatial relationships, hierarchies, and meanings, e.g. Brown (2006) on Mayan spatial cognition. PGIS capabilities need to understand and handle the appropriate degree of 'precision' required for different mapping purposes by different actors, thus responding to the question: 'precision for whom?'. There is a profound distinction between the 'representational' and the 'positional' accuracy of the objects seen in the map or GIS. Standard cartography and GIS tend to focus on the positional precision, whereas PGIS emphasises the fuller understanding of the objects being portrayed (McCall 2006). Aside from ontological and ideological arguments, there are pragmatic security grounds for optimising by reducing the level of precision, because the highly precise spatial information could fall into the wrong hands - a simple example being 'who should be able to know the precise location of cultural sites or valuable biomedical resources?'.

There are technical issues of representing this fuzziness and ambiguity through various GIS and graphics tools of transparent overlays, fuzzy graphics of points and lines, or dynamic GIS. The images employed in PGIS are rich in information and shared understanding; there is an incredible impact of visual images as communication and cartographic "spatial narratives". A picture is worth 'more than a 1000 words' because it is the qualitative improvement in 
information which creates the 'conviction' factor of visual images - although this can have negative as well as positive implications. The technical requirement is to translate 'group space preference maps' (local spatial knowledge) into GIS-compatible constructs that are on a legal or policy 'level playing-field' with other more powerful stakeholders, as with 'countermaps'.

\section{Characteristics of tools and methods}

Empowerment depends on developing tools and techniques that are accessible and userfriendly for acquiring and handling a variety of types of spatial knowledge in PGIS, not just maps. There are still technical issues of hardware and software design and operations to be resolved for implementing PGIS. The supporting technological capacities, especially for maintenance, are often deficient within communities or NGOs who want to use PGIS, but it is self-evident that over time, the technologies are increasingly adapted to user-friendliness and simplicity. A PGIS tool however, should not raise the expectations of local communities unrealistically by proffering a pretentious technology promising more than it can deliver

User-friendliness includes portability such as with Tablets, iPaqs, and GPS or Smartphones for mobile GIS, and user-compatible, flexible, interactive and freeware software, such as Google Earth and CyberTracker and GPS. It also includes material characteristics such as ruggedness, battery life, maintainability and cost. PGIS creates opportunities for more secure storage and ease of communication, for recording, protecting, exchanging, and sharing spatial information in digital or analogue.

The wide range of tools and techniques are not reviewed here in this paper, but see assessments of tools, e.g. Flavelle (2002); Nova Cartografia Social da Amazônia (n.d.); ACT Brazil (2008); Di Gessa - ILC (2008), CTA (2010) Training Materials; Corrigan \& Hay-Edie (2013). In particular, there are innovative methods of local information acquisition by communities, such as video (Boelens n.d.), UAVs (Paneque-Gálvez et al. 2014), and kites (Corrigan \& Hay-Edie 2013). 


\section{Protocols for Good Practice}

Requirements and objectives for 'good practice in PGIS applications' have been incorporated into a number of approaches worldwide, and with special reference to Latin America and indigenous North America. The guidelines can be simply categorised into the recommended good practices 'before', 'during', and 'after' the PGIS and P-mapping activities. A participatory approach ought to be seamless between these operational stages, with the participatory process starting early and eventually, not closing down, but morphing into further practices.

The concepts and principles of FPIC (Free, Prior, Informed Consent) are vitally important for participatory research anywhere, and especially so when the research activities involve indigenous communities (e.g. Schnarch 2004; Swiderska et al. 2012). General recommendations for good practice, and accounts of experiences are found in e.g. Rambaldi et al. (2006) on ethical practice, Fox et al. (2005) with experiences of negative and positive outcomes of PGIS, CTA 2010, Tobias (2010); Swiderska et al. 2012.

Canadian First Nations who were the first indigenous adopters and further developers of PGIS approaches have produced several training manuals and handbooks with practical accumulated advice on sound ethical and social participatory procedures, notably Chief Kelly's Moose (Terry Tobias), Mapping Our Land (Flavelle 2002), and Aberley (1999).

For Latin American experiences, mostly in Spanish or in Portuguese, there is well-developed material, including training videos, from: Nicaragua (Gonda et al. 2004 - video); Brazil (Nova Cartografia Social da Amazônia n.d.,); Peru (Shinai 2004, Orta Martínez 2010; RROMUEPATSRO 2010 - video); Colombia (Fuentes \& Reyes 2008); Bolivia (Evans et al. 2006); Venezuela (Poole 1995); Belize (Toledo Maya Council 1997); and covering many countries in Central and South America (ACT Brazil 2008, Herlihy \& Knapp 2003; Chapin \& Threlkeld 2001). 


\section{Challenges}

\section{Participation as process or product}

Practitioners point out that PGIS has or may have greater value in facilitating and promoting progressive changes (towards equity, empowerment etc.) - not through the output products, but through the drawn-our process of creating the PGIS, using the PGIS within, as part of, the participatory inclusion of 'multiple forms of knowledge'. Community mapping is as much about process as it is about 'getting the map done.' Elwood (2006) called this 'qualified GIS', and she emphasized the visual as communication and cartographic spatial narratives instead of the analytic. This issue is significant in the well-grounded debate on understanding 'participation' as being both process and position. In the application "participatory projects" in rural or community development, there is always the tension between the concrete outputs of the project, and gains in terms of participants' capacities, confidence, and empowerment.

\section{Elite accumulation of benefits of PGIS}

What is the intensity, authenticity, and veracity of the "participation" in PGIS? There are challenges in the conflicting interpretations and contested discourses of participation. Participation is an idealized concept, always criticisable as a straw man for not living up to the purity of the intent. PGIS, like any intervention intended to be participatory can both empower and marginalise within the community simultaneously (McCall \& Dunn 2012), such as in relation to gendered knowledge and power (e.g. Rocheleau \& Ross 1995; Willmer \& Ketzis1996; Wagner Berno de Almeida et al. 2009).

Examining the intensity of participation calls into question notions of 'community' that assume that goals are agreed upon and explicit. There are critical issues around the ownership of the geo-information and the products - who owns them? Who can use them? Who can add to, or delete them? - essentially, who benefits from the new forms of spatial knowledge?

This concern is valid for within the community as well for external actors, and the most politically-charged aspect of this is the concern about 'geo(information)-piracy', that is, the 
unauthorised elicitation and use of local indigenous knowledge about territories, boundaries, material resources and cultural or spiritual items.

\section{Re-presentation of spatial concepts and knowledge.}

The representation of individual or community mental maps, of people's cognitions of place and space, or the fuzzy prioritisations of people's needs and objectives in space, are fraught with ontological and epistemological challenges. For one of many examples, see Brown (2006) on Mayan cognitions of relative and absolute space.

Recognition of the cognitive gaps between local, especially indigenous, interpretations of space and values ascribed to places, and the pitfalls in 'mapping' them to 'western conventional' twodimensional maps (or GIS layers) in Euclidean space, was strongly asserted early on by e.g. Rundstrom 1990, 1995; Orlove 1993. This critical assessment of the potential for mapping or PGIS has been carried forward by e.g. Stocks 2003; Wainwright \& Bryan 2009; Sletto 2009, Sletto et al. 2010, 2013), and is especially critical with spatially representing cosmovisions (Read et al. 2010; Hirt 2012). Notwithstanding this, there are positive indications that technical devices in PGIS are improving enough to begin to cross the divide between mental maps / naïve geography and digital interpretations, through innovations in knowledge acquisition, cartography and visualization, and data structuring.

Deconstructionist critiques of PGIS further criticise it for the re-creation of local indigenous knowledge to and for an external focus, e.g. Sletto (2009) has termed this as 'deculturalisation' in the context of PGIS actions in Trinidad and Venezuela; also Sletto et al (2010) in Dominican Rep. He sees community-based mapping as a dualistic approach to power which subordinates local culture and 'local space', through the material and discursive domination of globalist and environmentalist interventions. 


\section{Maps are power}

Maps and other geo-information products are dangerous weapons, they can be employed progressively or regressively. "Maps are inseparable from the political and cultural contexts in which they are used" was the theme of the "Mapping for Indigenous Advocacy and Empowerment' Conference, in Vancouver, 2004. Similarly in the context of First Nations' struggles for restoration, Rundstrom (1990 p.156) argued forcefully for the need to look below the surface of the map to the underlying power structure. "The intentional meaning [of maps is] to assist in locating areas and to assign exclusive coordinates to them. The implicational meaning lies elsewhere in the related concepts of resource inventory, identification, allocation, and purchase of private property; property protection and access through thousands of miles of barbed-wire fencing and pavement; manifest destiny; and the geometry of American society. The act of designing and producing such a map is an action of subjugation and appropriation of nature ....."

\section{CONCLUSIONS}

An assertion of this paper is that participatory mapping and PGIS are rendered special because they address specific purposes which are identified and defined by the needs of the communities they are intended to be serving. The concomitant conditions being that the PGIS is implemented with sound procedures and ethical behaviour.

Communities and groups can be empowered and capacity-enhanced by involvement in PGIS processes. By building communicability between outsiders and insiders, PGIS legitimises the value of the endogenous knowledge and makes the PGIS tools more accessible and acceptable to local users. The communities' resulting entry into and control over handling PGIS technologies builds their capacity and confidence. Communities expand their horizons as they move from the particular to the general, by using PGIS (e.g. in a web GIS). They can better understand how local issues connect to wider regional or international issues, such as in 
monitoring invasions and land grabs or waste dumping, and it provides a functional link of solidarity to other threatened communities.

PGIS can empower communities in Latin America as elsewhere, by developing their technical and social and political capital and building confidence, to utilise their local and indigenous spatial knowledge (technical, livelihood, cultural and spiritual knowledge) in a respectful manner; to preserve the knowledge in a form which is sustainable and influential with external agencies; to equitably record, analyse, conserve and value the local knowledge of natural resources and cultural practices, and the needs and priorities of different groups in the community; and to advocate for community customary land and resource rights on the ground and in the constitutional framework, especially significant for native indigenous communities.

\section{REFERENCES}

Aberley, D. (1999) Giving the Land a Voice, Mapping our Home Places. Saltspring Island, BC: LTA Land Trust Alliance of British Columbia.

ACT Brazil: Ana Carolina Kalume, Ivaneide Bandeira, João Guilherme Nunes Cruz, Júlio César Borges, Marcelo Segalerba, Renata Carvalho Giglio, Thiago Ávila, Vasco van Roosmalen, i Wesley Pacheco. (Editorial Group) (2008) Methodology of Collaborative Cultural Mapping. Brasilia: $\begin{array}{llllll}\text { Amazon } & \text { Conservation } & \text { Team } & - & \text { ACT } & \text { Brazil }\end{array}$ http://www.equipe.org.br/publicacoes dentro.php?tipoid=1

Anta Fonseca, Salvador; Arturo V. Arreola Muñoz; Marco A. González Ortiz; and Jorge Acosta González (eds) (2006) Ordenamiento Territorial Comunitario: un debate de la sociedad civil hacia la construcción de políticas públicas. Mexico DF: INE - SEMARNAT Instituto Nacional de Ecología,

Arias, Pablo Daniel (2012) Nosotros Vamos a Dibujar Nuestro Propio Espacio Territorial. Reapropiación del Territorio y Apropiación de la Cartografía en la Zonal Pewence. Corpus. Archivos Virtuales de la Alteridad Americana 2 (1). Univ. de Mendoza, PhD Thesis

http://ppct.caicyt.gov.ar/index.php/corpus/article/view/905/1218 
Barrera-Bassols, Narciso; Zinck, J. Alfred; and van Ranst, E. (2009) Participatory soil survey: experience in working with a Mesoamerican indigenous community. Soil Use and Management $25,43-56$.

Bernard, Enrico; Luis Barbosa; and Raquel Carvalho (2011) Participatory GIS in a sustainable use reserve in Brazilian Amazonia: Implications for management and conservation. Applied Geography 31 (2) 564-572.

Boelens, Rutgerd (n.d.) Indigenous Water Rights in Ecuador. VIDEO.

Wageningen: Wageningen University http://www.iapad.org/applications/water/licto 2.htm

Brazenor, Clare A. (2000) The Spatial Dimensions of Native Title. Melbourne: Dept. of Geomatics, MSc Thesis. www.sli.unimelb.edu.au/research/publications/IPW/Clare thesis.pdf

Brown, Penelope (2006) Language, culture and cognition: the view from space.

Zeitschrift fur germanistische Linguistik 34, 64-868.

Carleton University (n.d.) Living Cybercartographic Atlas of Indigenous Perspectives and Knowledge. Ottawa: Carleton University, Geomatics and Cartographic Research Centre.

https://gcrc.carleton.ca/confluence/display/GCRCWEB/Living+Cybercartographic+Atlas+of+Indi genous+Perspectives+and+Knowledge

Chapin, Mac; Lamb, Zachary; and Threlkeld, Bill (2005) Mapping indigenous lands. Annual Review of Anthropology 34: 619-638.

Chapin, Mac; and Bill Threlkeld (2001) Indigenous Landscapes: A Study in Ethnocartography. Washington, DC: Environmental Law Institute, Center for the Support of Native Lands. http://www.elistore.org/reports detail.asp?ID=10805\&topic=International 
Cochran, David M. (2008) Placing geographic power in the hands of the people: the potential for participatory GIS in economic development. J. of Applied Research In Economic Development 5 (3)

Corrigan, C.; and Hay-Edie, T. (2013) A Toolkit to Support Conservation by Indigenous Peoples and Local Communities: Building Capacity and Sharing Knowledge for Indigenous Peoples' and Community Conserved Territories and Areas. (ICCAS) Cambridge: UNEP-WCMC

Cronkleton, Peter; Albornoz, Marco Antonio; Grenville Barnes; Kristen Evans; and Wil de Jong (2010) Social geomatics: participatory forest mapping to mediate resource conflict in the Bolivian Amazon. Human Ecology 38 (1) 65-76.

CTA (2010) Training Kit on Participatory Spatial Information Management and Communication. Wageningen: CTA, ACP-EU Technical Centre for Agricultural and Rural Co-operation (CTA) (English, Spanish, Portuguese versions) Coordinator: G. Rambaldi

\section{http://pgis-tk-en.cta.int/}

Dana, Peter H. (2008) Surveys of people and place. pp.494-518, IN: Wilson, John P.; and Stewart Fotheringham (eds) (2008) Handbook of Geographic Information Science. Oxford: Blackwell.

De Freitas, Débora M.; and Tagliani, Paulo Roberto A. (2009) The use of GIS for the integration of traditional and scientific knowledge in supporting artisanal fisheries management in southern Brazil. J. of Environmental Management 90 (6) 2071-2080.

Di Gessa, Stefano; contributers: Poole, Peter; and Bending, Timothy (2008) Participatory Mapping as a Tool for Empowerment. Experiences and Lessons Learned from the ILC Network. Rome: ILC International Land Coalition

Dunn, Marc Andre; and Smith, Derek A. (2011) The spatial patterns of Miskitu hunting in Northeastern Honduras: Lessons for wildlife management in tropical forests. $\underline{J}$. of Latin American Geography 10 (1) 85-108. 
Elwood, Sarah (2006) Critical issues in participatory GIS: Deconstructions, reconstructions, and new research directions. Transactions in GIS 10 (5): 693-708.

Evans, Kristen; de Jong, Wil; Miranda, P.; and Cronkleton, Peter (2006) Evaluating and Adapting Multidisciplinary Landscape Assessment in Forest-Dependent Communities in the Northern Bolivian Amazon. Bogor Barat: Center for International Forestry Research (CIFOR).

Fals-Borda, Orlando; and Luis E. Mora-Osejo (2003) Context and diffusion of knowledge. A critique of Eurocentrism. Action Research 1 (1) 29-37.

Finley-Brook, M.; and Offen, Karl (2009) Bounding the Commons: land demarcation in northeastern Nicaragua. Bulletin of Latin American Research 28, 343-363.

Flavelle, Alix (2002) Mapping Our Land: A Guide to Making Your Own Maps of Communities and Traditional Lands. Edmonton, AB: Lone Pine Foundation.

Flores de Melo, Antonio Willian; Sonaira Souza da Silva; Roberto de Alcântara Tavares; Julieta Matos Freschi; Renato Antônio Gavazzi; José Frankneile M. Silva; Benki Piyanko; Comunidade Ashaninka Apiwtxa; and Irving Foster Brown (2007) Aplicação de dados SRTM, sensoriamento remoto e SIG em etnomapeamento: o caso da Terra Indígena Kampa do Rio Amônia na fronteira Brasil-Acre/Peru-Ucayali. p. 5949-5956 IN: INPE (2007) Anais XIII Simpósio Brasileiro de Sensoriamento Remoto, Florianópolis, Brasil, abril 2007.

\section{http://marte.dpi.inpe.br/col/dpi.inpe.br/sbsr@80/2006/11.15.23.05/doc/5949-5956.pdf}

Foster Brown, I.; Alechandre, Andrea S.; Sassagawa, Hiromi S.Y.; and de Aquino, Maria A. (1995) Empowering local communities in landuse management: the Chico Mendes Extractive Reserve, Acre, Brasil. Cultural Survival Quarterly 18 (4) 54-57.

Fox, Jefferson; Krisnawati Suryanata; and Peter Hershock (eds) (2005) Mapping Communities: Ethics, Values, Practices. Honolulu HI: East-West Center. http://www.eastwestcenter.org/res-rppublicationdetails.asp?pub ID=1719. 
Freire, Paulo (1970) Pedagogy of the Oppressed. New York, NY: Continuum.

Freire, Paulo (1982) Creating alternative research methods. Learning to do it by doing it.

IN: Budd Hall, Arthur Gillette and Rajesh Tandon (eds) Creating Knowledge: A Monopoly. New Delhi: Society for Participatory Research in Asia. pp 29-37.

Fuentes, Mauricio; and Reyes, David (2008) Cartografía Participativa y Sistematización de Información Espacial. Metodología de Articulación de Cartografía Social y Sistemas de Información Geográfica. Bogotá: Alcaldía Mayor de Bogotá, Secretaría Distrital de Integración Social.

Gonda, Noémi; Denis Pommier; Osmin Rocha Vallecillo; et al. (2004) Prevención y Resolución de Conflictos en Tomo a la Tierra y los Recursos Naturales: Manual Practico de Mapeo Comunitario y Uso del GPS para Organizaciones Locales de Desarrollo. Managua: Unión Europea. www.agter.asso.fr/IMG/pdf/manual gps final 2da a.pdf

Gordon, Edmund T.; Galio C. Gurdián; and Charles R. Hale (2003) Rights, resources, and the social memory of struggle: reflections on a study of indigenous and Black community land rights on Nicaragua's Atlantic Coast. Human Organization 62 (4)

Green Maps. www.greenmap.org, www.greenmap.com/home/home.html

Heckenberger, Michael J. (2009) Mapping indigenous histories: collaboration, cultural heritage, and conservation in the Amazon. Collaborative Anthropologies 2, 9-32.

Herlihy, Peter H. (2003) Participatory research mapping of indigenous lands in Darién, Panama. Human Organization 62 (4)

Herlihy, Peter H.; and Knapp, Gregory (2003) Maps of, by, and for the peoples of Latin America. Human Organization 62 (4) 303-314.

Hirt, Irène (2012) Mapping dreams/dreaming maps: Bridging indigenous and western geographical knowledge. Cartographica 47 (2) 
ILO (1989) ILO Convention No.169. Indigenous and Tribal Peoples. Geneva: ILO. http://www.ilo.int/indigenous/Conventions/no169/lang--en/index.htm

Jardinet, Sylvanie (2006) Capacity development and PGIS for land demarcation: innovations from Nicaragua. Participatory Learning and Action 54: 67-73.

Kelly, John H.; Peter H. Herlihy and Derek A. Smith; Aida Ramos Viera; Andrew M. Hilburn; and Gerardo A. Hernández Cendejas (2010) Indigenous territoriality at the end of the social property era in Mexico. J. of Latin American Geography 9 (3) 161-181.

Korten, David C. (1986) Community Management. Asian Experience and Perspectives.

West Hartford, CT: Kumarian

López Urrego, Angela Patricia (2010) Una noción de territorio y los sistemas de información geográfica participativos: experiencia en una comunidad indígena del Amazonas colombiano. Revista UD y la Geomatica 4, 3-145

Martínez-Verduzco, Guillermo C.; J. Mauricio Galeana-Pizaña; and Gustavo M. Cruz-Bello (2011) Coupling community mapping and supervised classification to discriminate shade coffee from natural vegetation. Applied Geography 34 (May) 1-9.

McCall, Michael K. (2003) Seeking good governance in participatory-GIS: a review of processes and governance dimensions in applying GIS to participatory spatial planning. Habitat International 27(4): 549-573.

McCall, Michael K. (2006) Precision for whom? - Mapping ambiguity and certainty in (Participatory) GIS. Participatory Learning and Action 54: 114-119.

McCall, Michael K., and Dunn, Christine E. (2012) Geo-information tools for participatory spatial planning: Fulfilling the criteria for 'good' governance? Geoforum 43 (1) 81-94 
Méndez, V.E.; R. Lok; and E. Somarriba (2001) Interdisciplinary analysis of homegardens in Nicaragua: micro-zonation, plant use and socioeconomic importance. Agroforestry Systems 51 (2) $85-96$.

Nietschmann, Bernard (1995) Defending the Miskito reefs with maps and GPS. Mapping with sail, scuba, and satellite. Cultural Survival Quarterly $18(4)$ : 34-37.

Nova Cartografia Social da Amazônia (nd) Belem i Manaus: PPGCS-UFPA Universidade Federal do Amazones - Programa de Pos-Graduacao Sociedade e Cultura na Amazonia. (PNCSA/PPGSCAUFAM/ Fond.

Ford)

http://dgp.cnpq.br/buscaoperacional/detalhegrupo.jsp?grupo=431170382CJT5E

O'Connor, Loretta; and Peter C. Kroefges (2008) The land remembers: landscape terms and place names in Lowland Chontal of Oaxaca, Mexico. Language Sciences 30, 291-315

Offen, Karl H. (2003) Narrating place and identity, or mapping Miskitu land claims in northeastern Nicaragua. Human Organization 62 (4) 382-392

Offen, Karl H. (2011) The territorial turn: Making Black territories in Pacific Colombia. J. of Latin American Geography 2 (2) 43-73.

Orlove, Benjamin (1993) The ethnography of maps: the cultural and social contexts of cartographic representation in Peru. Cartographica 30 (1) 29-46.

Orta Martínez, Martí (2010) Oil frontiers in the Peruvian Amazon. Impacts of oil extraction for the Achuar of Río Corrientes. Barcelona: Universitat Autònoma de Barcelona (UAB), Institut de Ciència i Tecnologia Ambientals (ICTA), PhD in Environmental Science.

Paneque-Gálvez, Jaime; Michael K. McCall, Brian M. Napoletano, Serge A. Wich, and Lian Pin Koh (2014 fc) Small drones for community-based forest monitoring: an assessment of their feasibility and potential in tropical areas. Forests 
Peters-Guarin, Graciela; and McCall, Michael K. (2011) Participatory mapping and monitoring of forest carbon services using freeware: Cybertracker and Google Earth. Chap. 8. IN: M. Skutsch (ed.) (2010) Community Forest Monitoring for the Carbon Market: Opportunities under REDD. London: Earthscan

Poole, Peter (1995) Indigenous Peoples, Mapping and Biodiversity Conservation: An Analysis of Current Activities and Opportunities for Applying Geomatics Technologies. Washington, D.C.: World Wildlife Fund, Biodiversity Support Programme, People and Forests Program Discussion Paper. http://www.bsponline.org/publications/showhtml.

Poole, Peter (2005) The Ye'kuana mapping project. Chap. 12 IN: J. P. Brosius; A. Tsin; and C. Zerner (eds.) (2005) Communities and Conservation: Histories and Politics of Community-based Natural Resource Management. Walnut Creek CA: AltaMira Press.

Poole, Peter (2006) Is there life after tenure mapping? Participatory Learning and Action 54: 41-49.

RROMUEPATSRO (2010) Mapping the Historical-Cultural Space of the Yanesha, Perú

VIDEO http://www.youtube.com/watch?v=7GbOQQQH69Q

Rambaldi, Giacomo; Chambers, Robert; McCall, Michael; and Fox, Jefferson (2006) Practical ethics for PGIS practitioners, facilitators, technology intermediaries, and researchers. $\begin{array}{lllll}\text { Participatory } & \text { Learning } & \text { And } & \text { Action } & \text { 54, }\end{array}$ http://www.iied.org/NR/agbioliv/pla notes/documents/ch14 rambaldi pp106-113.pdf

Read, Jane M; José M.V. Fragoso; Kirsten M. Silvius; Jeffrey Luzar; Han Overman; Anthony Cummings; Sean T. Giery; and L. Flamarion de Oliveira (2010) Space, place, and hunting patterns among indigenous peoples of the Guyanese Rupununi region. J. of Latin American Geography 9 (3) 213-243.

Reyes-García, Victoria; Martí Orta-Martínez; Maximilien Gueze; Ana C. Luz; Jaime PanequeGálvez; Manuel J. Macía; Joan Pino; and TAPS Bolivian Study Team (2012) Does participatory 
mapping increase conflicts? A randomized evaluation in the Bolivian Amazon. Applied Geography 34, 650-658

Rocheleau, Dianne E.; and Ross, Laurie (1995) Trees as tools, trees as text: struggles over resources in Zambrana-Chacuey, Dominican Republic. Antipode 27, 407-428.

Rundstrom, Robert A. (1990) A cultural interpretation of Inuit map accuracy. Geographical Review 80 (2) 155-168.

Rundstrom, Robert A. (1995) GIS, indigenous peoples and epistemological diversity. Cartography \& GIS 22 (1) 45-57.

Schnarch, Brian (2004) Ownership, Control, Access, and Possession (OCAP) or selfdetermination applied to research. $\quad \underline{\text { s of }}$ Aboriginal Health 1 http://www.research.utoronto.ca/ethics/pdf/human/nonspecific/OCAP\%20principles.pdf

Shinai (2004) Aquí Vivimos Bien. Kamyeti Notimaigzi Aka. Territorio y Uso de Recursos de los Pueblos Indigenas de la Reserva Kugapakori Nahua. Lima: Garfield Foundation, IUCN-NC, Nouvelle Planete, Oxfam America, \& Rainforest Foundation.

Sletto, Bjørn Ingmunn (2009) "We Drew What We Imagined" Participatory mapping, performance, and the arts of landscape making. Current Anthropology 50 (4) 443-476.

Sletto, Bjorn; Muñoz, Solange; Shawn M. Strange; Rosa E. Donoso; and Martin Thomen (2010) El Rincón de los Olvidados: Participatory GIS, experiential learning and critical pedagogy in Santo Domingo, Dominican Republic. Journal of Latin American Geography 9 (3) 111-135.

Sletto, Bjorn Ingmunn; Bryan, Joe; Torrado, Marla; Hale, Charles; and Barry, Deborah (2013) Territorialidad, mapeo participativo y política sobre los recursos naturales: la experiencia de América Latina. Cuadernos de Geografía - Revista Colombiana de Geografía 22 (2) 193-209. 
Smith, Richard Chase; Margarita Benavides; Mario Pariona; and Ermeto Tuesta (2003) Mapping the past and the future: geomatics and indigenous territories in the Peruvian Amazon. Human Organization 62 (4) 357-368

Smith, Julia K.; Lina Sarmiento; Dimas Acevedo; Mayanín Rodríguez; and Rafael Romero (2009) Un método participativo para mapeo de fincas y recolección de información agrícola aplicable a diferentes escalas espaciales. Interciencia 34 (7) 479-486

Smith, Derek A.; Peter H. Herlihy, Aida Ramos Viera, John H. Kelly, Andrew M. Hilburn, Miguel Aguilar Robledo, and Jerome E. Dobson (2012) Using participatory research mapping and GIS to explore local geographic knowledge of indigenous landscapes in Mexico. Focus on Geography (Winter 2012) 119-124

Stocks, Anthony (2003) Mapping dreams in Nicaragua's Bosawas Reserve. Human Organization $62(4)$

Stocks, Anthony; Beauvais, J.; and Jarquin, L. (2000) El activisimo ecologico indigena en Nicaragua: demarcacion y legalizacion de tierras indígenas en Bosawas. Wani (J. of the Nicaraguan Caribbean) 25, 6-21.

Swiderska, Krystyna; Kanchi Kohli; Harry Jonas; Holly Shrumm; Wim Hiemstra; and Maria Julia Oliva (eds) (2012) Biodiversity and culture: exploring community protocols, rights and consent. London: IIED, Participatory Learning and Action No. 65.

Tobias, Terry N. (ed.) (2010) Living Proof: The Essential Data-Collection Guide for Indigenous Use-and-Occupancy Map Surveys. North Vancouver: Aboriginal Mapping Network (AMN). http://nativemaps.org/node/3684

Toledo Maya Cultural Council (1997) Maya Atlas: the Struggle to Preserve Maya Land in Southern Belize. Berkeley, CA: North Atlantic Books.

UNDRIP (2007) United Nations Declaration on the Rights of Indigenous Peoples. New York, NY: UN. http://www.un.org/esa/socdev/unpfii/documents/DRIPS en.pdf 
Vélez Torres, Irene; Rátiva Gaona, Sandra; y Varela, Daniel (2012) Cartografía social como metodología participativa y colaborativa de investigación en el territorio afrodescendiente de la cuenca alta del río Cauca. Cuadernos de Geografía, Revista Colombiana de Geografía 21 (2) 5973.

Wagner Berno de Almeida, Alfredo; Sales dos Santos, Glademir; e Lima, Luís Augusto Pereira (eds) (2009) Estigmatização e Território: Mapeamento Situacional dos Indígenas em Manaus. Manaus: Projeto Nova Cartografia Social da Amazônia / Editora da Universidade Federal do Amazonas.

http://www.novacartografiasocial.com/arquivos/publicacoes/livro estigmatização.pdf

Wainwright, Joel; and Joe Bryan (2009) Cartography, territory, property: Postcolonial reflections on indigenous counter-mapping in Nicaragua and Belize. Cultural Geographies 16 (2) $153-178$

Willmer, Abigail; and Jennifer Ketzis (1998) Participatory gender resource mapping: a case study in rural Honduras. Participatory Learning and Action 33, 17-22.

Wood, Denis (1992) The Power of Maps. New York, NY: Guilford.

Wood, Denis with: John Fels and John Krygier (2010) Rethinking the Power of Maps. New York, NY: Guilford. 